\title{
İran'da Siyasal Ekoller Üzerine Bir Değerlendirme
}

\author{
Hüdayi Sayın* \& Ahmet Çırakoğlu**
}

\section{$\ddot{O} z$}

1979 Devrimi sonrasında İran'a hâkim olan İslami ideoloji ülkenin siyasal sistemini de bütünüyle dönüştürdü. 2500 yıllık monarşi rejiminin lağvedilen kurumlarının yerine şeriata dayalı yeni kurumlar getirildi. Geçici hükümet döneminde yaşanan görece özgürlük ortamından kısa süre sonra, Velayet-i Fakih doktrini ve idealizm felsefesi temelinde şekillenen jakobenist İslamcılık, devrim sürecinin sürükleyicisi olan birçok siyasi akımı sistemden tasfiye etti. İslami ideolojinin faklı söylemleri de devrim liderinin iktidarında yönetimden uzaklaştırıldı. Humeyni'nin ardından yönetici kadro içerisinde farklı hizipler oluşmaya başladı ve yürütme kanadında devrimin idealist ruhu, yerini pragmatist politikalara bıraktı. Sistemi idealizmin açmazlarından kurtarma söyleminde olan pragmatistler, statüko yanlısı muhafazakâr kesimden ayrışarak reformistlerle ittifaka girdi. Reformistlerin yürütme erkini elde etmesini sağlayan bu ittifak, muhafazakârların popülist politikalarına yenilerek rejimin ağır baskılarına maruz kaldı. Günümüze değin bu temelde Muhafazakârlar ve Reformistler etrafinda şekillenen siyasal sisteme, mevcut dönemde Ilımlılar olarak tanımlanan yeni bir akım eklemlenmiş durumdadır. Bu makalede Reformistler, Muhafazakârlar ve Ilımlılar bloğu tarafından oluşturulan siyasal ortam ve bu ortamı meydana getiren koşullar analiz edilmiştir.

Anahtar Kelimeler: 1979 Devrimi, İran'ın Siyasal Yapıs1, Reformistler, Muhafazakârlar, Ilımlılar

\footnotetext{
* Dr, İstanbul Yeni Yüzyıl Üniversitesi, TR, İktisadi ve İdari Bilimler Fakültesi, orcid. org/0000-0002-8994-4088, hudayi.sayin@yeniyuzyil.edu.tr

** Doktora aday1, TR, orcid.org/0000-0001-5491-1780, irday.geruri@gmail.com
} 


\title{
An Assessment on Political Wings in Iran
}

\author{
Hüdayi Sayın* \& Ahmet Çırakoğlu**
}

\begin{abstract}
After the 1979 Revolution, the Islamic ideology that dominated Iran, transformed the country's political system completely. New institutions based on shariah replaced the abolished institutions of the 2500-year-old monarchy regime. Shortly after the relative freedom environment during the provisional government, the Jacobeanist Islamism, which was shaped on the basis of the Velayat-i Faqih doctrine and the philosophy of idealism, eliminated many political movements that led the process to the revolution of the system. The different discourses of Islamic ideology were removed from the government under the leadership of the revolutionary leader. Following Khomeini, different factions began to form within the executive staff, and the idealist spirit of revolution in the executive wing was replaced by pragmatist policies. The pragmatists, who were in the rhetoric of saving the system from the impasse of idealism, allied with the reformists by separating themselves from the conservative pro-status quo. This alliance, which allowed the reformists to acquire the executive power, was defeated by the populist policies of the conservatives and underwent heavy pressure from the regime. In the current period, a new political trend, the Moderates is added to the already existing system shaped by the Conservatives and the Reformists. In this article, the political environment created by the Reformists, Conservatives and Moderate blocs and the conditions that constitute this environment are analyzed.
\end{abstract}

Keywords: 1979 Revolution, Political Structure of Iran, Reformists, Conservatives, Moderates

\footnotetext{
* Dr. Istanbul Yeni Yuzyil University, TR, Faculty of Economics and Administrative Sciences, orcid.org/0000-0002-8994-4088, hudayi.sayin@yeniyuzyil.edu.tr

** PhD Candidate, TR, orcid.org/0000-0001-5491-1780, irday.geruri@gmail.com
} 


\section{Giriş: Dün, Bugün ve "Yarının Tarihi”"ni Anlamaya Çalışmak}

Küresel söylemiyle bütün dünyada etki uyandıran ve eylemleriyle uluslararası dengeleri önemli ölçüde etkileyen İran'daki büyük devrim hareketinin üzerinden tam 40 yll geçti. Günümüzde İran siyasal sistemi, güçlü kişilikler etrafında şekillenen siyasal elitler eliyle yönetiliyor. Siyasal alanı sahiplenen mukimler, desteğine ihtiyaç duyduğu halkın taleplerini önemsemekle birlikte, güçlerini önemli ölçüde sistem içerisinde yürüttükleri denge politikalarından ve kurdukları siyasal ilişkilerden almaktadırlar. Böyle bir ortamda iç ve diş politik gelişmeler kurumsallığın çok ötesinde güçlü kişilikler ve sistemin mutlak hâkimi olan lider/ler etrafında şekilleniyor.

İran siyasal sisteminin günümüz yapılanmasının temelleri komünist-liberal cepheleşmesinin şekillendirdiği Soğuk Savaş dönemine kadar dayandırılabilir. 1950'li yıllarda kabaca siyasal İslamcı, ulusalcı ve sosyalist/ komünist olarak sınıflandırabileceğimiz siyasal bloklar, 1979 Devrimi sonrasında yaşanan gelişmeler sebebiyle ya sistemden tasfiye edilmişler, ya da üzerlerindeki ideolojik hırkaları çıkararak İslami Cumhuriyet Partisi içerisinde siyaset yapmaya mecbur edilmişlerdir.

İran siyasal sistemi, yapısındaki oligarşik özelliğinin yanında, aslen şer’i ve cumhurî kurumların sentezinden meydana gelir. Bununla birlikte dini kurumların sistem içerisindeki ağırlığı, günümüzde var olan sorunların ve sistem tartışmalarının temel sebebi gibi görülmektedir. Özgün bir yapıya sahip olan İran siyasal sistemi içerisinde yer alan aktör ve kurumları, modern siyasal terminolojinin dışında kalan tanımlamalar sebebiyle karşılaştırmalı siyaset açısından incelemek oldukça güçtür. Kavramsallaştırmalar genellikle kurumlar yerine kişiler ve onların etrafında toplananlar üzerinden yapılır. Bu tanımlama konusundaki bir diğer güçlük ise, aktörlerin söylemlerine hâkim olan ideolojik dayanak, temsil ettikleri toplumsal kitlenin talepleri ve ittifakların sürekli değişimidir. İran'da yaşanan gelişmeleri ve devletin yapısını kendi değerleri üzerinden değil de Batı merkezli kavramsallaştırmalar üzerinden açıklamaya çalışmak ${ }^{1}$ bu durumu iyice çıkmaza

İran'ın kendi tarihi ve öz kültürü üzerinden teorik açıklamalar yapma çabasında olanlar bu konuda farklı bakış açıları sunmaktadırlar. İranlı akademisyen Moazami, Batı toplumlarını açıklarken kullanılan kuramlar ve bu toplumlar üzerine yapılan kavramsallaştırmaların yerine, Batı dışı toplumlar üzerinde yapılan çıkarımları önceleyen yöntemlerle bir analiz yapılması önerisinde bulunmakta ve bunu eserlerine yansıtmaktadır. İran konusunda da Batılı teoriler üzerinden analizler yapmak yerine, 
sokmaktadır. ${ }^{2}$ Buna karşın, İran yazınında da yer alan siyasal kavramlar metin boyunca esas alınacaktır. Örneğin, klasik-modern sağ ve sol, radikal, muhafazakâr, reformist, 1lımlı kavramları ve bunların hangi aktörlerce temsil edildiği konusunda İran yazınında yer alan sınıflandırma ${ }^{3}$ ve tanımlamalar ${ }^{4}$ kullanılacaktır. Metinde, devrim sonrasına yoğunlaşan bir tarihsel gelişim çizgisi tartışılmaya çalışılacak ve bunun üzerinden tespitler yapılmaya gayret gösterilecektir.

\subsection{Kavramsal Çerçeve}

Sağ kanat ve sol kanat terimleri genel olarak bireyin politik yönelimlerini ve konumunu tanımlamak için kullanılır. Bu kavramların siyasi anlamda kullanımı Fransız Devrimi yıllarına kadar dayanmaktadır. Devrim sonrasinda yapilan ilk meclis toplantısinda radikaller (devrimciler) sol tarafta otururken, kralı destekleyen aristokratlar ise kralın sağında oturmaktaydı ve bu oturma düzeni ileriki yıllarda da böyle devam etti. Kısa süre sonra sağ terimi gericilik veya kraliyet taraftarı olarak, sol terimi ise devrimci veya eşitlikçi anlamlarında anlaşılmaya ve kullanılmaya başlandı. Siyasal ideolojileri doğrusal olarak bir şemaya oturtmamız gerekirse liberalizmin ortada yer aldığı bir düzlemde sosyalizm ve daha radikal olan komünizm sol kanadı oluştururken, muhafazakârlık ve daha radikalize olan faşizm sağ kanadı meydana getirir. ${ }^{5}$ Cemil Meriç'e göre sağcılık (muhafazakâr an-

olayları kendi bakış açısıyla irdelemiş ve özgün tezler geliştirmiştir (Behrooz Moazami, Iran'da Devlet, Din ve Devrim, 1796'dan Bugüne, çev. Bahar Bilgen (İstanbul: İletişim Yayınlar1, 2018), 286-289).

2 Sami Oğuz ve Ruşen Çakır, Hatemi’nin İran'ı (İstanbul: İletişim Yayınları, 2000), 47-49.

3 İran siyasal sistemindeki sağ, muhafazakâr, yeni sağ, eski sağ, sol, yeni sol gibi siyasal ayrımlar, yeni sol akımın ana oluşumu olan Sazıman-1 Mucahidin-i İnkılab-i İslami-ye İran (İran İslam Devrimi Mücahitleri Örgütü)'ın resmi yayın organı Asr-e Ma tarafından yapılmış ve bu politik terimler sonraki yıllarda İran siyasal cephelerin tanımlanmasında sıkça kullanılmıştır (Sami Oğuz, çev. "Görkemli 23 Mayıs Destanının Değerlendirilmesi,” Birikim Dergisi, say1 101 (Eylül 1997), Erişim tarihi: 10.02.2019, http://www.birikimdergisi.com/birikim-yazi/4674/gorkemli-23-mayis-destaninindegerlendirilmesi\#.XIltEaD7QdV).

$4 \quad$ Wilfried Buchta, Who Rules Iran?: The Structure of Power in the Islamic Republic, (Washington: The Washington Institute for Near East Policy and the Konrad Adenauer Stiftung, 2000), 11-22, Erişim tarihi: 09.03.2019, https://www.washingtoninstitute.org/ uploads/Documents/pubs/WhoRulesIran.pdf.

5 Andrew Heywood, Siyasî İdeolojiler: Bir Giriş, 5. baskı, çev. Ahmet Kemal Bayram vd. (Ankara: Adres Yayınları, 2013), 32-33. 
lamıyla) ezeli değerlerin koruyuculuğunu üstlenirken, solculuk özgürlük, ilericilik ve eşitliktir. ${ }^{6}$ Sağ-sol ayrımını aşırılık-1lımlılık, eşitlik-eşitsizlik, özgürlük-yetke gibi ikilikler üzerinden yorumlayan Norberto Bobbio'ya göre, sağ ve sol birbiri sayesinde varlığını devam ettirir. Sağın olmadığı yerde sol, solun olmadığ 1 yerde sağ olmaz. ${ }^{7}$ Aşırı sağ özgürlük karşıtı ve eşitsizlikçi, aşırı sol ise eşitlikçidir. Merkez sağ ve merkez solda ise eşitlik ve özgürlük eşit oranda temsil olunur. ${ }^{8}$ Sağ siyaset daha çok toplumun var olan değerleri üzerinden kendi varlığını inşa ettiğini sloganlaştırır. Bu sebeple sağ siyasette mevcut olana dönük koruma eğilimi öne çıkar. Bu konumuyla sağcılık doğal olarak muhafazakârlık eğilimini de içinde barındırmaktadır. ${ }^{9}$ Sağın önceliğini insanın tabiatı, özgürlük-eşitlik ilişkisi, gelenek-teamül-sadakat ve kapitalist yap1 içerisinde özel mülkiyet oluştururken, solun temel kavramlarını insan doğası, sosyal değişim, eşitlik, ilericilik ve modernlik çatısı altında kapitalist sistemin analizi meydana getirir. İslami sol kavramı ise ilk olarak 1980'lerin başında Urvetu'l-Vuska dergisinin oluşturduğu geleneği yeniden canlandırmak adına Hasan Hanefi tarafından çıkarılan dergide gündeme getirilmiştir. ${ }^{10}$

II. Dünya Savaşı sonrasında gelişen şartların birikimiyle birlikte 1970 sonrasında otoriter muhafazakârlı̆̆ın yerini alan "yeni sağ" terimi, iktisadi libertenyanizm (özgürlükçülük) ile devlet ve sosyal alandaki otoriteryanizmi bütünleştirme girişimidir. Çeşitli tarihsel etkenlerin ürünü olan yeni sağ fikirlerin ortaya çıkmasında dönemin sosyo-politik şartları ve uluslararası ortam etkili olmuştur. Yeni sağın; neo-liberal olarak adlandırılan devlet-

6 Muzaffer Emin Göksu, "Sağc1lık ve Solculuğun Ötesinde," Tezkire Dergisi 9, say1 17 (Ekim/Kasım 2000): 58-59, Erişim tarihi: 15.02.2019, http://isamveri.org/pdfdrg/ D01353/2000_17/2000_17_GOKSUME.pdf.

$7 \quad$ Norberto Bobbio, Să̆ ve Sol: Bir Politik Ayrımın Anlamı, çev. Zühal Yılmaz (Ankara: Dost Kitabevi, 1999), 58.

8 Metin Uçar, "Klasik Bir Ayrımın Ötesine Geçememek: Siyasal Farklılığın Ölçütü Olarak Sağ-Sol,” Liberal Düşünce, say1 40, (Güz 2005): 337, Erişim tarihi: 28.02.2019, http://www.libertedownload.com/LD/arsiv/40/18-metin-ucar-siyasal-farkliliginolcutu-olarak-sag-sol.pdf.

9 Ahmet Kesgin, "İnsanın Meşruiyet Kaygısı ya da Kendini Sağcı Olarak İnşa Etmek," Toplum Bilimleri Dergisi 5, say1 9 (Ocak-Haziran 2011): 195, Erişim tarihi: 18.02.2019, http:/www.toplumbilimleri.com/files/f131f25e-03d2-4fd4-8d0c324a3ad8803812\%20Ahmet\%20KESGIN.pdf.

10 Murat Kayacan, "Sağ(cılık) ve Sol(culuk) Kavramları ile Bu Kavramların Kur'an Meallerindeki Kullanımları," Marife Dergisi 10, say1 3 (Kış 2010): 292-293, Erişim tarihi: 11.01.2019, http://dergipark.gov.tr/download/article-file/494078. 
çilik karşıtı ve serbest piyasa anlayışına sahip olan liberal versiyonu ile neo-muhafazakârlık olarak adlandırılan yasalara, kamusal ahlaka ve ulusal kimliğe önem veren muhafazakâr versiyonu vardır. ${ }^{11}$ Yeni sağ aslen; piyasa ekonomisi, ekonomik verimlilik ve birey özgürlügünü temele alan neo-liberalizm ve otoriteye bağl1lığ 1 , geleneksel yaşamı, kanun ve kurallara uyumu önemseyen neo-muhafazakârlığın bir sentezi şeklinde oluşmuştur. ${ }^{12}$

1990’lı yıllara gelindiğinde mevcut konjonktürün etkisiyle özellikle sosyoekonomik özgürlükler ve refah devleti tartışmalarını içerisinde barındıran yeni sol kavramı ortaya çıkmıştır. Değişimin kaçınılmazlığı noktasında geleneksel soldan ayrışan liberal-demokratik eksenli yeni solun savunuları çoğulcu, demokratik ve katılımcı bir toplum, bireysel hak ve sorumluluklar ve toplumsal değişimdir. Yeni sol düşünürler bireysel özerklik ve sosyal adalet fikrini uzlaştırmaya çalışırlar. 1970'li yılların sonlarından itibaren yeni sağın katılımcılık yerine tüketimciliği geliştiren vatandaş anlayışını ortaya çıkardığını savunan yeni sol, vatandaşlığın pasif hizmet tüketicisi yerine aktif katılımcı bir rolünün olması gerektiği üzerinde durur. Siyasal alan ve demokrasiye olan güvenin yeniden tesisle toplumsal bütünleşmeyi sağlayarak modernleştirmeyi derinleştirmek iddiası yeni solun popüler olmasının en önemli sebeplerinden biridir. ${ }^{13}$

Etimolojik olarak korumak ve muhafaza etmek anlamlarına gelen Latin kökenli “conserve" sözcügünden gelen ve Batı'da conservative olarak kullanılan muhafazakâr kelimesi, ${ }^{14}$ Arapçada korumak, ezberde tutmak anlamına gelen "hıfz" kökünden türetilmiş olan muhafaza ve Farsçada eden anlamına gelen "kar" sözcüklerinin birleşiminden meydana gelmiştir. Türkçede ise bu kelime saklamak, korumak, bellekte tutmak anlamlarında kullanılmaktadır. ${ }^{15}$ Siyasal anlamıyla muhafazakârlık sözcügü ilk ola-

11 Heywood, Siyasî İdeolojiler, 103-108.

12 Fatih Duman, "Modern Siyasal İdeolojiler," içinde Feodaliteden Küreselleşmeye: Temel Kavram ve Süreçler, ed. Tevfik Erdem (Ankara: Lotus Yayınevi, 2006), 147.

13 Alev Özkazanç, "Yeni Sağdan Sonra: Yeni Sol, Siyasi İktidar ve Meşruiyet," Ankara Üniversitesi Siyasal Bilgiler Fakültesi GETA Tartışma Metinleri, say1 24 (Mart 2000), 2-22, Erişim tarihi: 02.03.2019, http://politics.ankara.edu.tr/dergi/tartisma/2000/ siyasi-iktidar.pdf.

14 Pınar Tuzcu, "Yeni Sağ, Muhafaza(kâr)lık ve Göç," içinde Yeni Să̆ Yeni Sol, der. Armağan Öztürk (Ankara: Phoenix Yayınevi, 2010), 476.

15 Mustafa Uluçakar, "Muhafazakâr Demokrasi Söylemi Üzerine Bir İnceleme," Alternatif Politika 10, say1 3 (2018): 352, Erişim tarihi: 03.03.2019, http://alternatifpolitika.com/ site/cilt/10/sayi/3/3-Ulucakar-Muhafazakar-Demokrasi-Soylemi.pdf. 
rak Fransa'da 1818'de Chateaubriand'in kurduğu radikal bir gazete olan Muhafazakâr'da kullanıldı. İngiltere'de ise 1830 'da J. W. Croker'in makalesinde görüldü ve 1832 'de Muhafazakâr Parti adıyla bir parti kuruldu. Kelime aynı dönemlerde Almanya'da kullanılmaya başlandı. Bunun yanında muhafazakârlığın doğuşu oldukça geç yıllara uzanmaktadır. Tarihçiler genel ilke olarak muhafazakârlığın doğuşunu ilk büyük karşı devrimci metinlerin yayınlanmasına kadar dayandırırlar. Hatta bazı yazarlar bunun da öncesinde Cicero, Saint Augustin ve Thomas More'u muhafazakâr kategorisinde değerlendirirler. Kimileri tarafindan liberal olarak nitelendirilen İskoç asıllı İngiliz düşünce ve siyaset insanı Edmund Burke, muhafazakârlığın kurucusu olarak gösterilir. ${ }^{16}$ Muhafazakâr ilkelerin ilk ve klasik savunuları Burke'ün 1789 tarihinde yazdığ1 "Fransa'daki Devrim Üzerine Düşünceler" adlı eserinde yer ald $1{ }^{17}$ ve muhafazakârlığın felsefi varlığı bu eser ile vücut buldu. ${ }^{18}$ Temelde anti-modern olan muhafazakâr doktrin, Avrupalıların geleneksel sosyo-politik düzenlerini savunmak için oluşmuş, Burke ve takipçilerine göre Fransız Devrimi'ne karş1 geliştirilen tepkiden doğmuştur. Buradan hareketle muhafazakârlığın anti-devrimci olduğu sonucuna varılabilir. ${ }^{19}$ Bu bağlamda siyasal muhafazakârlık Fransa, İngiltere, Almanya ve ABD'de siyasal ideoloji, halk düşüncesi ve parti politikası olarak kullanılmıştır. Aydınlanma, Fransız Devrimi ve Sanayileşme süreçleri siyasal muhafazakârlığı kurumlaştıran olguların başında gelmektedir. Bu süreçlerin olgunlaştırdığ 1 siyasal muhafazakârlık; toplumu, gelenekleri, dini, tarihi değerleri, var olan düzeni ve özel mülkiyeti savunurken, devrimi, bireyciliği ve akılcıllığ reddeder. ${ }^{20}$ Manevi yönden irdelendiğinde muhafazakârların çoğuna göre mevcut düzenin yaratıcısı ve koruyucusu tanrıdır. ${ }^{21}$ Muhafazakârlığın siyasal ideoloji hüviyetine bürün-

16 Philippe Beneton, Muhafazakârlık, çev. Cüneyt Akalın (İstanbul: İletişim Yayınları, 2011), 7-9.

17 Heywood, Siyasî İdeolojiler, 83.

18 Robert A. Nisbet, Muhafazakârlık: Düşve Gerçek, çev. M. Fatih Serenli, Fatih Bülbül (Ankara: Kadim Yayınları, 2007), 51.

19 Beneton, Muhafazakârlık, 11.

20 Hüseyin Şeyhanlığlu, "Siyasal Muhafazakârlığın Temel İlkeleri," Dicle Üniversitesi İktisadi ve İdari Bilimler Fakültesi Dergisi 1, say1 1 (Kış 2011): 84-87, Erişim tarihi: 21.02.2019, http://dergipark.gov.tr/download/article-file/370660.

21 Mehmet Vural, Siyaset Felsefesi Açısından Muhafazakârlık, 2. bask1 (Ankara: Elis Yayınları, 2007), 55. 
düğü y1llardan sonra bu kavram, mevcut durumun muhafaza edilmesini savunan ve sosyal alanda radikal değişimlere kuşkuyla bakan siyasal bir tutum olarak tanımlandı. Genel anlamıla geleneksel kurumların özünü korumayı benimseyen muhafazakârlık, bu kurumlarda meydana gelecek değişiklik ya da reformlara karşı tavır sergileyen bir ideolojidir. ${ }^{22}$

Muhafazakâr ideolojinin kaynă̆ı, Aydınlanma dönemindeki büyük çalkantılara ve ardından gelen istikrasız durulma süreçlerine kadar dayandırılabilir. Aydınlanma değerlerine yöneltilen eleştiriler, muhafazakâr düşünce geleneğinin temelini oluşturmuş, muhafazakâr siyasal ideolojinin kavram ve ilkeleri de bu temelden hareketle şekillenmiştir. Tüm sistemi sırf aklı kullanarak yıkmak ve yeniden kurmak isteyenlerle mücadele etmek üzere ortaya çıkmış olan muhafazakârlık, ${ }^{23}$ Aydınlanmacı akıl anlayışına, bu fikirlerden doğan siyasi projelere ve toplumun bu projeler vasitasılyla geleneksel toplumsal kurumların dönüştürülmesine karşı çıarak toplumu sekülerleştiren devrimci projelerden ve projecilerden korumayı amaçlamakta, devrimci dönüşüme karşı tedrici değişimi savunmaktadır. ${ }^{24}$ Aydınlanmacı fikirlerle hareket eden bireylerin toplumu dönüştürmek ve yeniden düzenlemek ad1na yapacakları eylemler doğal evrimi etkileyerek toplumsal dengeyi bozacağından dolayı tehlike arz eder. Muhafazakârlar aydınlanma düşüncesinin bireyciliği ve toplum mühendisliği tavrına karşı, uzun yıllar süren toplumsal evrimin kazanımların koruma ve doğal seyrinde devam ettirerek gelenekleri muhafaza etme amacı taşırlar. ${ }^{25}$ Muhafazakârlığın öncülleri kendi ülkelerinde kurumsallaşmış dini değerlere büyük önem vermişler, dini değerleri devletin, toplumun ve bireyin hayatında önemli bir konuma yerleştirmişlerdir. ${ }^{26} \mathrm{Bu}$ açıdan muhafazakârlık, mevcut sistemin kurumsal yapılarının ortadan kaldırılmasına karşı bir savunma mekanizması niteliğindedir.

\footnotetext{
22 Uluçakar, "Muhafazakâr Demokrasi," 352.

23 Bekir Berat Özipek, Muhafazakârlı: Akıl Toplum ve Siyaset (Ankara: Liberte Yayınları, 2004), 16, 32-33.

24 Duman, "Modern Siyasal İdeolojiler," 119-120.

25 Doğancan Özsel, "Radikalizm ve Muhafazakâr Düşünce: Yeni Muhafazakârlık Ne Kadar Yeni?," içinde Yeni Să̆ Yeni Sol, der. Armağan Öztürk (Ankara: Phoenix Yayınevi, 2010), 421-422.

26 Şeyhanlıŏlu, "Siyasal Muhafazakârlığın," 96.
} 
Muhafazakârlı̆̆ın doğasında gelenekselcilik vardır. ${ }^{27}$ Muhafazakârlara göre bu ideolojinin olmazsa olmazı olarak görülen din, bireysel bir inanç olmanın ötesinde toplumun birlikteliğini muhafaza ederek toplumsal istikrarı koruma görevini üstlenir. Bu bağlamda muhafazakârların savunduğu İslam'1 merkeze alan düşünce ve faaliyetleri geleneksel İslami vurgulardan ayırmak ve Müslüman bireyi tanımlamak için kullanılan, ümmetin sorunlarına ortaklaşa bir sorumlulukla yaklaşma bilincini telkin eden İslamcılık kavramı, klasik İslam kavramından farklı olarak siyasal bir sistemi ifade etmektedir. ${ }^{28}$ Geleneksel muhafazakârlı̆̆ın organik ve kendiliğindenci toplumsal gelişimi savunan tavrının, muhafazakârların değer atfettiği toplumsal mirası yok edeceği korkusuyla terk edilmesi ve buradan hareketle muhafazakâr değerlerin radikal dönüşümleri de öngören politikalar vas1tasıyla savunulması anlayışı muhafazakârlığın radikal versiyonunu meydana getirmiştir. ${ }^{29}$ Türkçeye düzeltimcilik olarak tercüme edebileceğimiz reformculuk kavramı ise, devrime ve gericiliğe karşı kademeli gelişmeye duyulan inanc1, bir sorun veya sıkıntıya çare olmak için geliştirilen eylem ve politikaları ifade eder. ${ }^{30}$

Siyasal partileri, halkın desteğiyle devlet mekanizmasını ele geçirmeye ve devamlılığını sağlamaya çalışan, istikrarlı bir örgüte sahip olan siyasal topluluklar olarak tanımlamamız mümkündür. $\mathrm{Bu}$ anlamda gelişmiş toplumlarda siyasal katılımın gerçekleşmesinde başlıca araç olan modern siyasal partiler 19. yüzyılda ortaya çıkmıştır. Toplumların kendi içerisinde yaşadığ1 yöresel-bölgesel çatışmalar, ulusal elit içerisindeki çatışmalar, özgül çıkar çatışmaları ve ideolojik çatışmalar sonucunda yaşanan soysal bölünmeler ise muhafazakâr ve liberal partiler, komünist ve faşist partiler, çitçi partileri ve bölgesel partiler, ayrılıkçı partiler olmak üzere dört farklı parti tipolojisini ortaya çıkarmıştır. ${ }^{31}$

27 Tuzcu, "Yeni Sağ," 476-477.

28 Uluçakar, "Muhafazakâr Demokrasi," 353.

29 Özsel, "Radikalizm ve Muhafazakâr Düşünce," 427.

30 Heywood, Siyasî İdeolojiler, 328.

31 Ergun Özbudun, Siyasal Partiler, 3. bask1 (Ankara: Sevinç Matbaas1, 1979), 4, 35-38. 


\subsection{Araştırmanın Yöntemi}

$\mathrm{Bu}$ araştırma nitel araştırma teknikleri ile gerçekleştirilmiştir. Nitel araştırmalar genellikle tarihsel ve bilimsel araştırma türlerinde kullanılır. ${ }^{32}$ Şemsiye bir kavram olarak nitel araştırma, "gözlem, görüşme ve doküman analizi gibi nitel bilgi toplama yöntemlerinin kullanıldığı, algıların ve olayların doğal ortamda gerçekçi ve bütüncül bir biçimde ortaya konmasına yönelik nitel bir sürecin izlendiği araştırma olarak" tanımlanabilir. ${ }^{33}$ Nitel araştırma yöntemi bir problemi keşfederek onun hakkında detaylı düşünceler geliştirir, araştırma sorularını genel bir şekilde beyan eder, elde ettiği verileri analiz ederek verilerin daha büyük anlamlarını yorumlamaya çalışır ve en önemlisi de araştırmacının öznel görüşlerini yansıtabilir. ${ }^{34}$ Genellemenin öncelikli amaç olmadığı nitel araştırma, kavram ve kuram oluşturmaya yönelik modellerdir. Bu yöntemde amaç, insanın kendi toplumsal çevresini nasıl ürettiğini, yaşadığı fiziksel ortamı nasıl algıladığını, yorumladığını anlamaktır.

Araştırmada İran'da siyasal ekollerin gelişimi 1979 Devrimi merkeze alınarak tartışılmaya çalışılmıştır. Bu gelişim siyaset bilimi kavramları çerçevesinde değerlendirilmeye çalışılmış, İran'a özgü farklılıklar ortaya konularak ülkede siyasal kurumsallaşmanın izlekleri sürülmeye gayret edilmiştir. Bu izlekler, sosyo-politik düzeyde devlet özünün anlaşılacağı nesneler olarak "devlet fikrinin" 35 doğacağı siyasal oydaşmanın zeminini oluşturacaklardır.

32 Kemal Kartal, Yöntembilim (Ankara: Detay Yayıncılık, 2015), 99.

33 Ali Yıldırım, "Nitel Araştırma Yöntemlerinin Temel Özellikleri ve Eğitim Araştırmalarındaki Yeri ve Önemi," Eğitim ve Bilim 23, say1 112 (1999): 10-16, Erişim tarihi: 14.01.2019, http://egitimvebilim.ted.org.tr/index.php/EB/article/ view/5326/1485.

34 John W. Creswell, Educational Research: Planning, Conducting, and Evaluating Quantitative and Qualitative Research, 4th edition (Boston: Pearson Education Inc., 2012), 16, Erişim tarihi: 11.03.2019, http://basu.nahad.ir/uploads/creswell.pdf.

35 Barry Buzan, İnsanlar, Devletler \& Korku, çev. Emre Çıtak (İstanbul: Röle Akademik Yayınc1lik, 2015), 69-83. 


\section{2. İran'da Güncel Siyasal Cephelerin Oluşumunu Anlamaya Çalışmak}

İran siyasal sisteminin sürükleyicileri olan sosyalistler, komünistler ve milliyetçiler devrim sonrası yerlerini, ulemanın kontrolündeki İslamcı radikal grupların temsil ettiği yeni orta sınıfa bıraktı. Devrim öncesi modernleşme süreçlerinin taşıyıcısı, küresel sermaye ile ilişkili büyük sermaye grupları, yarg1 erki ve yüksek rütbeli memurlardan oluşan devlet elitleri yeni aktif siyasal sistem içindeki 1lımlı ve liberal oluşumlara destek verseler de, siyasal gelecek tahminlerindeki isabetsizlik ve popüler siyaset deneyiminden uzaklıkları nedeniyle kalıcı etki yaratamadılar. Din adamlarının denetimindeki İslamcı radikal gruplar ise küçük-orta büyüklükteki tüccar, çözülen kırdan kentlere akmış, şehrin periferisini doldurmuş kitlelerin desteğini aldı. Başlangıçta, yeni devletin inşa görevini üstlenen birinci grup kaynaklı teknokratlar ile onların toplumsal desteğini oluşturan ikinci grubun meydana getirdiği kitleler arasındaki koalisyon, devletin yönetim şekli, iç ve dış politika konusundaki anlaşmazlıklar sebebiyle dağıldı. İslamcı radikaller yönetimde etkinleşirken, 1lıml1-liberal görüşü temsil edenler sistemin dışına itildi. İslamcı radikallerin güçlenmesindeki ana etken, kendilerini destekleyen kitlenin politik sisteme mobilize olma isteği ve anayasanın karar mekanizmalarını işgal eden dini elitlere verdiği imtiyazdı. Ulusal Cephe, İran Özgürlük Hareketi ve İran Halk Partisi tarafindan oluşturulan geçiş hükümeti tabandan gelen baskılara dayanamayarak iktidarı radikal devrimcilere teslim etmek zorunda kald.$^{36}$

Şii ulema, aralarındaki görüş ayrılıklarını minimalize etmeyi başararak İran Devrimi öncesinde Pehlevi monarşisine karşı tek vücut oldu. Fakat ortak düşmanın ortadan kalkmasıyla birlikte devrimin hemen ertesinde aynı sıcaklığıyla tekrar gün yüzüne çıkan bu görüş ayrılıkları, günümüz İran siyasal sisteminde var olan cepheleşmenin oluşmasında büyük pay sahibi oldu. Velayet-i Fakih çerçevesinde ulema egemenliğinde teokratik bir yönetimi savunan radikal muhafazakârlar ana cepheyi oluştururken, devlet yönetiminde çoğulculuğu savunan bir kısım üst düzey ulema, ${ }^{37}$ din adamlarının dünyevi siyasete müdahale etmediği, siyasi işlerin sadece si-

\footnotetext{
36 Hüseyin Beşiriye, Zeminaha-yı İçtimai-ye İnkılab-e Iran, 2. bask1, İngilizceden çev. Ali Erdestani (Tehran: Neşr-i Nigâh-1 Moesser, 1394), 31-32.

37 Muhammed Bestinigâr, “Talegani An Çenan Kebûd,” Endişe-i Puya 2, sayı 14 (1393): 29.
} 
yasetçiler tarafından idare olunduğu katılımcı demokrasiyi savunduklarından dolayı reformcu ve modernist cephe olarak adlandırıldılar. Bu görüşler devrimin ardından Humeyni'ye yakın din adamlarının kurduğu İslami Cumhuriyet Partisi ${ }^{38}$ ve Şeriatmedari'nin liderliğindeki Müslüman Halkın Cumhuriyetçi Partisi ${ }^{39}$ ile kurumlaştı. ${ }^{40}$

Devrimin ardından radikal İslamcılar ve 1lımlı liberal gruplar kesim arasında baş gösteren görüş ayrılıkları İslami Cumhuriyet düşüncesinin genel kabulüyle ortadan kalkmış gibi görünse de Humeyni’ye yakın din adam-

38 Devrim sonrasında din adamlarının formel bir örgüt altında birleştirilmesi amacıyla kurulan Hizb-e Cumhuri-ye İslami, İnkılâbın ilk yıllarında kurulan en önemli siyasi partiydi. Partinin kurucuları; Ayetullah Muhammed Huseyin Behişti, Hamaney, Rafsancani, Ayetullah Musavi Erdebili, Celalleddin-i Fasi ve Abbas Şeybani'dir. Partinin ilk genel sekreteri Behişti'ydi (Emir Abbas İntizam, An Su-ye İttiham: 1357 Şehriver-1360 Hordad, Cilt 1, 2. bask1 (Tehran: Neşr-i Ney, 1381), 218). Parti, cami yapılanmaları şeklinde faaliyet göstererek, din adamlarının Şii İslamcılık anlayışını güçlendirmek ve kitleleri bu düşünce etrafinda seferber etmeyi amaçladı (Serpil Üşür, Din, Siyaset ve Kadın: Iran Devrimi (İstanbul: Alan Yayıncılık, 1991), 114). Temel olarak Allah'ın hâkimiyetini savunan parti bütün yasaların şeriata uygun olmasını ve devletin fakihler tarafından idare olunmasını istemekteydi. Partinin en güçlü destekçileri Tahran Mücadeleci Din Adamları Cemiyeti ve Kum İlim Medreseleri Müderrisler Topluluğu'ydu (Hüseyin Beşiriye, Iran'da Devlet, Toplum ve Siyaset, çev. Mehmet Koç (İstanbul: Ağaç Kitabevi Yayınları, 2009), 26-27). İslam fikhı temel alınarak kurulan partide süreç içerisinde yaşanan geleneksel fikıh ve modern fikıh tartışmaları, süreç içerisinde partinin sağ ve sol olarak ikiye ayrılmasına sebep olmuştur. Cumhurbaşkanı Recai ve başbakan Bahoner'in Mücahidin-i Halk tarafından gerçekleştirilen suikastlar sonucunda öldürülmelerinin ardından başbakanlığa getirilen Mir Huseyin Musavi'nin partinin genel sekreterliğini yaptığ 1 yıllarda, sol grubun düşüncesi partiye egemen oldu (Abdullah Yegin, "İran Siyasetini Anlama Kılavuzu," Siyaset, Ekonomi ve Toplum Araştırmaları Merkezi, Yayın no. 25 (Haziran 2013): 30, Erişim tarihi: 23.03.2019, http://file.setav.org/Files/Pdf/20130610163244_iransiyaseti_web.pdf). Görüş ayrılıkları sonucunda sol eğilimli olarak gelişen bu düşünceler, bugün İran siyasal sisteminde var olan muhafazakâr-reformist ayrışmasının önemli bir ayağını oluşturmaktadır.

39 Merci-i taklid olan Ayetullahu'l-Uzma Muhammed Kazım Şeriatmedari tarafından kurulan Hizb-e Cumhuri-ye Halk-1 Müselman, Humeyni'nin Velayet-i Fakih teorisine ve ulemanın siyasette etkin olması fikrine tepki gösteren en önemli oluşumlardan biridir (İntizam, An Su-ye Ittiham, 218). Kurucu meclis tarafindan dini olmayan Avrupai tarzda bir anayasanın onaylanmasını savunan parti, aydınlar, serbest meslek sahipleri ve yeni orta sınıf arasında itibar kazandı (Beşiriye, Iran'da Devlet, 28). Partinin amacı, Humeyni'nin Velayet-i Fakih anlayışına ve din adamlarının siyaseti yönetmesi görüşüne karşı, halkın yönetimde daha fazla söz sahibi olduğu İslami demokrasi rejimini vücuda getirmektir. Fakat muhafazakâr ve modernist din adamları arasında yaşanan bu mücadele sonunda Humeyni galip gelmiş, parti Batı ajanlığı suçlamasıyla kapatılarak, lideri Şeriatmedari siyasetin dişına itilmiştir (Üşür, Din, Siyaset ve Kadın, 118).

Üşür, Din, Siyaset ve Kadın, 116-118. 
larının İslami Cumhuriyet Partisi'ni kurmasıyla birlikte, genelde liberal İslamcı çizgide olan geçici hükümetle radikal İslamcılar arasında yaşanan görüş ayrılıklarını iyice belirginleştirdi ve bu durum da kitlesel ve bütünsel bir devrimin teokratik yapıya yönelmesinin başlangıcı oldu. Geçici hükümetin yönetimden ayrılmak durumunda birakılmasıyla birlikte sistemin hâkimiyeti bütünüyle popülist muhafazakârların kontrolüne geçti. ${ }^{41}$ İlk etapta İslami kesimle ittifak yaparak devrime öncülük eden ana unsurlar olan liberal-milliyetçi Ulusal Cephe ve komünist/sosyalist Tudeh Partisi tasfiye edildi. Sonrasında ise, İslamcı kanadın liberal-cumhuriyetçi bloğunu oluşturan İran Özgülük Hareketi’nden gelen yeni devletin ilk cumhurbaşkanı Ebu'l-Hasan Beni Sadr ve başbakanlık makamına getirilen Mehdi Bazergan, din adamlarının politik alandaki etkinliklerinin sınırlanması gerekliliğinden yana görüş beyan eden Ayetullah Şeriatmedari, onun bu görüşleri ile aynı çizgide olan Müslüman Halkın Cumhuriyetçi Partisi ve bu yaklaşımları savunan çeşitli oluşumlar radikal devrimciler eliyle sistem dışına itildi. ${ }^{42}$

Muhafazakârların kontrolündeki siyasal sistem içerisinde faaliyet gösteren yaklaşık seksen bin ruhani arasında radikal, liberal, mutedil ve tarafsız olmak üzere farklı fikirler etrafinda bütünleşen dört ana grup bulunmaktaydı. Siyasete nispeten uzak olan müstakil mollalar ise toplumsal alanda önemli nüfuza sahipti. Humeyni'nin çizgisinde olan ve onun yaklaşımını benimseyen radikal mollalar, devrim felsefesinden ödün verilmemesinden ve şer'i hükümlerin tavizsiz uygulanmasından yanaydılar. Velayet-i Fakih felsefesini şiar edinen radikal mollalar, devrim sonrasında Fransız İnkılâbı'ndaki jakobenler gibi siyasete hemen dâhil oldular ve İslam Fedaileri, İslam Devrimi Mücahitleri, İslami Dernekler Koalisyonu, İslami Milletler Partisi ve İslami Cumhuriyet Partisi gibi örgütlenmeler adiyla sisteme entegre oldular. Humeyni'nin eski öğrencilerinden olan Musavi Erdebili, Behişti, Hamaney, Rafsancani, Mehdevi Kani, Montazeri, Rabbani Emleki, Cevad Bahonar, Musavi Tehrani, Natık Nuri gibi bazı önemli şahsiyetler devrim sonrasında yeni devletin kurumsallaşmasında önemli rol oynadılar. Liberal mollalar, entelektüel arka planları sebebiyle sosyo-kültürel ve eğitimsel ba-

${ }^{41}$ Beşiriye, Iran'da Devlet, 34-38.

42 Yüksel Taşkın, "Devrim Sonrası İran'da Siyaset: Aktörler, Stratejiler ve Gelecek," İstanbul Üniversitesi Siyasal Bilgiler Fakültesi Dergisi, say1 39 (Ekim 2008): 24, Erişim tarihi: 06.04.2019, http://dergipark.gov.tr/download/article-file/5309. 
kışlarıyla radikallerden ayrışmakla birlikte İslam Şeriatı'nı da savunmaktaydılar. Konjonktüre göre tavır alma stratejisi geliştiren mutedil mollalar, devrimden sonra direkt olarak siyasetle etkileşmemiş, gelişmeleri rasyonalist bir pencereden temkinli şekilde izleyerek siyasal duruma göre belli konumlarda yer almışlardır. Tarafsız mollalar, elinden geldiğince tarafsız davranmaya özen göstererek herhangi bir siyasal eğilime yönelmemeyi başaran din adamlarından oluşmaktaydı. Müstakil mollalar ise, dinsel yorum yapabilecek yetkinliğe sahip olduğundan dolayı herhangi bir bağ1 olmaksızın kitleleri arkasından sürükleyebilen ve otoritesi sayesinde bu kitlelere öncülük edebilen güçlü dini şahsiyetlerden meydana gelmekteydi. Halkın Mücahitleri Örgütü’nün desteklediği müstakil mollalardan biri olan Seyyid Mahmud Ayetullah Talegani ve Ali Şeriati'nin eski hocası Şeyh Ali Tehrani gibi önemli kişilikler İslam hükümetinin meclis tarafından idare olunmasını istiyor, Velayet-i Fakih düşüncesinin siyasal yapı içerisindeki etkinliğini reddediyordu. Diğer taraftan mollaların haricinde, ekserisi dini entelektüeller ve üniversite öğrencilerinden oluşan Mücadeleci Müslümanlar Hareketi, Müslüman Halkın Özgürlük Hareketi, İslami Özgürlük Şuras1, Halkın Mücahitleri Örgütü benzeri radikal gruplar da İslami hükümetten yanaydılar, ama Velayet-i Fakih kurumunun siyasetin tepesinde yer almasına karşı çıkarak, devleti halk meclisinin yönetmesi gerektiğini dile getirmekteydiler. Tüm bu karmaşa alanında mücadeleden galip çıkan Humeyni, şahsına, devrimci felsefeye ve İslami sistemin aleyhine faaliyet gösteren güçlü kişilikleri ve örgütsel yapıları kısa süre zarfında pasifize ederek Velayet-i Fakih ideolojisini siyasal sistemin temeline yerleştirmeyi başard1 ${ }^{43}$

\section{Humeyni Sonrası İran'da Siyasal Gelişimler}

Devrimden sonraki ilk yıllarda devrimci ideolojinin sisteme hâkimiyeti iki aşamada meydana geldi. İslamcı radikaller, Şah döneminin siyasal arenasında etkili olan ulusalcı ve sosyalist-komünist bloğun tasfiyesinin hemen ardından, İslami kesim içerisinde farklı görüşleri dillendiren liberal İslamcı ve İslami sol bloğu da tasfiye ettiler. Bu aşamanın başarılı şekilde tamamlanmasının ardından, ulemanın toplumsal ve politik alan üzerindeki denetimin sınırlılığı-sınırsızlığıyla ilgili tartışmalar iktidarın sahibi olan

43 Beşiriye, Zeminaha-yl, 189, 236-240. 
din adamları arasında yeni bir bölünmeye sebep oldu. İmam'ın Yolu olarak kendisini isimlendiren İslami Cumhuriyet Partisi Başkanı olan Hüseyin Behişti liderliğindeki bir grup Uzmanlar Konseyi'nin sınırsız yetkilere sahip olması gerektiğini savunurken, Hüccetiye hareketi ${ }^{44}$ etrafinda toplanan ikinci bir grupsa ulemanın sadece dini alanı denetlemekle sınırlı kalması gerekliliğini savunmaktayd $1 .{ }^{45}$ İmam'ın Yolu bloğu devrimci İslam çizgisinin devaml1lı̆̆ düşüncesinde hareket ederken, Hüccetiye hareketi gelenekçi muhafazakâr blok etrafinda örgütlendi.

İran-Irak Savaşı sonrasında Hüccetiye ile giriştiği mücadeleyi kazanan İmam'ın Yolundakiler, kendi içinde bir bölünme daha yaşayarak radikaller ve pragmatikler olarak ikiye ayrıld. Devrimin ilk yıllarında Musavi, Hamaney, Montazeri ve Rafsancani'nin de içerisinde yer aldığı İmam'ın Yolundakiler, Batı karşıtlı̆̆ını, Irak ile savaşının devamını, devrim ihracını ve devletçi bir ekonomiyi savunmaktaydı. İran siyasetinin önemli figürlerinden biri olan Rafsancani, Humeyni'nin son dönemlerinde bu fikirlerin nispeten uzağında kaldı. Humeyni'nin vefatından önce Velayet-i Fakih hükümleri doğrultusunda ulemanın siyasal sistemin bütününü kontrol edip yönetmesi yaklaşımı ile siyasal gelişmelerin teknokratlarca yönetilmesi düşüncesi arasındaki uzlaşmazlık yeniden ortaya çıktı. Humeyni, ulemanın bu sınırsız yetkisine karşı geliştirdiği eleştirel tavır nedeniyle halefi olarak ilan ettiği Montazeri'yi de henüz hayattayken sistemin dışına itti. ${ }^{46}$ İslami Cumhuriyet Partisi mollaların arasında yaşanan fikir ayrılıklarının

44 Devrim öncesinde Bahaîlere karşı Şeyh Mahmud Halebî tarafından Meşhed şehrinde kurulan tarikat, zaman içerisinde yaşadığı değişim sebebiyle kaosun dünyaya hâkim olduğu bir ortamda Hz. Mehdi'nin ortaya çıkacağını savunarak kaosu teşvik eden düşünceleri yaymaya başladı (Babek Şahit, “İran'ın Millî Güvenliği ve Dinî Tarikatların Tehdidi," Tebriz Araştırmaları Enstitüsü, 20 Şubat 2018, Erişim tarihi: 09.04.2019, http://tebaren.org/?p=1371). Mehdilik temelli olduğu için ulemanın aktif siyasi faaliyetlere girişmesine karşı çıkmaktaydı. Onlara göre eğer bir İslam devleti kurulacaksa bu ancak Hz. Mehdi'nin zuhuruyla mümkün olabilirdi. Bu hareketin savunucuları doğal olarak devrimci ideolojiyle çelişen görüşleri sebebiyle zaman içerisinde Humeyni'nin fikirlerine de karşı çıkmışlardır (Cemil Hakyemez, "Günümüz İran Şiiliğinde Mehdilik Beklentisinin Siyasi Boyutu," Uluslararası Mehdilik Sempozyumu Bildirileri, ed. Mehmet Tıraşçı, Hasan Özalp, Maruf Çakır (Sivas: Cumhuriyet Üniversitesi Matbaas1, 2018), 518, Erişim tarihi: 12.04.2019, http://www. cumhuriyet.edu.tr/userfiles/file/Mehdilik_Sempozyumu.pdf).

45 Özgür Üşenmez, "İran ve Rejim İstikrarı,” Dokuz Eylül Üniversitesi Sosyal Bilimler Enstitüsü Dergisi 17, say1 3 (2015): 394, Erişim tarihi: 28.02.2019, http://dx.doi. org/10.16953/deusbed.90907.

46 Taşkın, "Devrim Sonrası," 25-26. 
neden olduğu bölünmeleri engellemek üzere Humeyni'nin izniyle kapat1larak partisiz hayata geçildiyse de bu defa da iktisadi politikalar ve meclis seçimlerinde listelerin denetlenmesi konusuyla ilgili fikir ayrıllğ 1 yaşand 1 ve ulema 1988'de Mücadeleci Din Adamları Cemiyeti ve Direnişçi Din Adamları Birliği isimleriyle iki ana bloğa ayrıldd. ${ }^{47}$

Humeyni'nin ölümünden sonra Rehberlik makamına Hamaney (1989-...) ve Cumhurbaşkanlığı makamına Rafsancani (1989-1997) geldi. Muhafazakârlar, radikaller ve pragmatikler İmam'in Yolu hareketini en iyi temsil ettikleri savunusuyla kendi içerisinde mücadeleye giriştiler. Humeyni sonrasının gelişmeleri içinde tartışmalı bir sürecin sonunda göreve gelen, ulema arasında saygınlığ1 ve otoritesi hayli az olan Hamaney'in statükoyu koruyucu politikaları, siyasi açıdan önemli bir figür olan ve uzun dönemde kendi kontrolünde bir devlet yapısı inşa etmeyi planlayan Rafsancani tarafından sessizce izlenmekteydi. ${ }^{48}$ Sol-popülist bir pozisyona sahip olan radikaller, eşitlikçi, halkçı bir çizgi içinde devrimin merkez söylemlerinden sosyal adalet vurgulu ABD karşıtı duruşun sürdürülmesini istiyorlardı. Popülist politikalardan ziyade sistemi koruma misyonu üstlenen ve merkez sağ temsil eden Muhafazakârlar, radikallerin toprak reformu taleplerine karş1 çıkıp, geleneksel Pazar esnafinı desteklerken; Rafsancani etrafında toplanan pragmatikler ise devrimci idealizmin uzağında, küresel ekonomik sistemle uyum içerisinde realist bir politika eşliğinde teokrasiyi önemsiyorlardı. Sistemin başında yer alan Hamaney'in bu üç blok arasındaki mücadelede muhafazakârlardan yana tavır sergilemesi güç dengesinin yerleşmesinde belirleyici oldu. Muhafazakârlar, belli bir nüfuza sahip oldukları Anayasayı Koruyucular Konseyi'nin yanında yargı erki ve askeriyede de etkinliğini artırdı. Buna karşılık, Uzmanlar Meclisi ve Düzenin Yararını Teşhis Konseyi'nde Rafsancani'yi destekleyen kesim söz sahibi olurken, İslami Şura Meclisi'ndeki güç dengesi her üç grup arasında dağılmaktaydi. ${ }^{49}$

Rafsancani'nin cumhurbaşkanlığı zamanında muhafazakârlar ve pragmatikler arasında oluşturulan ittifak, devrimin sürekliliğini savunan radikalle-

47 Mustafa Keskin, "İran'da Siyasal Ayrışmanın Temelleri: Sağ ve Sol," Akademik Perspektif, 31 Mayıs 2013, Erişim tarihi: 21.04.2018, http://akademikperspektif. com/2013/05/31/iranda-siyasal-ayrismanintemelleri-sag-ve-sol/.

48 Üşenmez, "İran ve Rejim,” 397.

49 Taşkın, "Devrim Sonrası," 27-28. 
rin zayıflamasına ve yenilgisine zemin hazırladı. Nebevi, Kerrubi ve Muhteşemi gibi sol cenahın önemli temsilcileri bu süreçte baskı altına alındı. Rafsancani, İslami Cumhuriyet Partisi'nin içinde yer alan üç blok içinde merkez sağı temsil eden muhafazakârlara yaklaştı. Kendisi ve çevresinde toplanan pragmatikler, Batı merkezli küresel sistemle bütünleşme ve toplumsal değişim sürecinin anayasal güvencelerini oluşturma taleplerini temsil ediyorlardı. Fakat 1990'lı yıllar boyunca Batı'yla ılımlı dış politika, ekonomik değişim ve kültürel politikalar karşısında rejimin gösterdiği direnç muhafazakârlarla olan ittifakın zedelenmesine yol açtı. Mevcut ortam 1997 tarihli cumhurbaşkanlığ seçimlerinde Hatemi önderliğindeki değişim hareketini öne çıkardı. Muhafazakârların baskılarına rağmen reformist çizgisiyle dikkat çeken Hatemi (1997-2005), Rafsancani'nin etrafinda toplanan pragmatiklerin sol cenahla kurduğu koalisyon sayesinde halkın $\% 70$ 'inin desteğini alarak cumhurbaşkanı seçildi. ${ }^{50}$

Muhafazakârların pragmatiklerle yaşadığı görüş ayrılıklarını derinleştiren bu olaylar sirasinda, radikallerin de devrimci ve popülist İslami soldan, görece liberal sola doğru belli bir yönelim gösterdikleri gözlendi. İran halk1nın reform taleplerini görmezden gelip 1979 Devrimi'nin inşa ettiği statükonun devamından yana tavır alan muhafazakârların uğradığı itibar kaybı ve seçimde aldıkları ağır yenilgi sonrası, bu kez muhafazakârların karşısında radikal kimliğinden sıyrılan İslamcı sol ile pragmatikler ittifakı meydana geldi. 1996 yılındaki meclis seçimlerinde bu liberal İslamcı sol eğilim, Rafsancani taraftarlarınca kurulan İran'ın İnşasının Yürütücüleri Partisi'ni destekleyerek, 1997'deki cumhurbaşkanlığ 1 seçim sürecinde doğacak olan Hatemi önderliğindeki reformist ittifakın da temellerini oluşturdu. ${ }^{51}$

Genel itibariyle kentli orta sinıf temsil eden Hatemi'nin reformist politikalarını uygulamadaki isteksizliği ve yavaş tavrı, büyük beklentilerle kendisine destek veren geniş halk kitlelerinin değişim taleplerini karş1layamadı. 2005 seçimlerinde reform taraftarı seçmenin önemli bir kısmı, radikallerin boşalttığı alana hitap eden ve onların alternatifi olarak görülen muhafazakârlara yönelim gösterdi. İran devlet aygıtının çelik çekirdeğini oluşturan Rehberlik Makamı, Anayasayı Koruyucular Konseyi, Devrim Muhafizları ve Yargı erki içinde zayıf bir temsil oranına sahip olan reformistler, bu baskı aygıtlarının desteğini alan ve giderek radikalleşen

\footnotetext{
50 Üşenmez, “İran ve Rejim,” 398-399.

51 Taşkın, "Devrim Sonrası,, 28-30.
} 
muhafazakârlar karşısında yenilgiye uğradı ve radikal muhafazakârların yeni adayı Mahmud Ahmedinejad cumhurbaşkanı (2005-2013) seçildi. Kendilerini Yeşil Hareket olarak adlandıran reform taraftarı kitleler, 2009 cumhurbaşkanlığı seçimlerine hile karıştırıldığg iddiasıyla Arap Baharı'nın arifesinde sokaklara döküldüler. Seçim sürecinde, kentli alt sınıflar ve kırsal kesimlerin desteğini alamayan reformist muhalefet, Velayet-i Fakih ve Rehber'in yetkilerine getirdikleri eleştiriler nedeniyle İran merkezi yapısına ve baskı aygitlarına hâkim olan radikal muhafazakârlar tarafından sert şekilde bastırıld1. ${ }^{52}$

Günün sonunda, reformistlerle muhafazakârlar arasındaki cepheleşmeyi artıran bu olaylar ve Ahmedinejad tarafindan uygulanan sert politikaların halk tarafindan benimsenmemesi, radikal muhafazakârlara tabanda olan desteğin azalmasına sebep oldu. ${ }^{53}$ Oluşan otoriterleşme ve baskıdan bunalan halk, sert politik çatışmacı ortamın yarattığı yorgunluktan, muhafazakâr ve reformist her iki kanadın 1lımlılarının oluşturduğu bloğa sığındı. Ilımlı lider Hasan Ruhani, 1lımlı reformistlerin yanında muhafazakârların 1lımlı kısmının da desteğini alarak cumhurbaşkanı seçildi.

\section{Siyasal Cepheleşmeler}

Devrim yıllarından itibaren değişen ittifaklar etrafında şekillenen İran siyaseti, sistemi domine eden temel iki siyasal oluşuma günümüzde bir yenisini daha eklemlemiş durumdadır. Birinci akımı İslami tabana hitap eden mollalar, ithal ikameci bir ekonomik modelin çıkarlarını koruduğu küçük-orta tüccardan oluşan pazar esnafı, kentlerin periferisinde ve kırsal alanda yaşayan, dinsel duyarlılıkları kuvvetli olan alt sınıfların desteğini alan Muhafazakârlar (Usulgeralar) oluşturmaktadır. İkinci akım çoğunluğu aydın, kentli orta sınıflar ve küresel sistemle bütünleşmek isteyen büyük sermaye gruplarının desteklediği Reformistler (Islahtalepler) meydana getirmektedir. ${ }^{54}$ Sert çatışmacı ortamdan yorulan halkın yönelim göster-

52 Üşenmez, "İran ve Rejim,” 399-403.

53 Mustafa Caner, "Ruhani'nin Politik Performans1," Sakarya Üniversitesi Ortadoğu Enstitüsü, 01 Eylül 2014, Erişim tarihi: 07.05.2019, https://ormer.sakarya.edu. tr/20,3,,12,ruhani_nin_politik_performansi.html?hilight=ruhani|reformist.

54 Dinmuhammed Ametbek, "İran Cumhurbaşkanlığı Seçimleri," Ankara Kriz ve Siyaset Araştırmaları Merkezi, 15 Mayıs 2017, Erişim tarihi: 12.01.2019, https://ankasam.org/ iran-cumhurbaskanligi-secimleri/. 
diği üçüncü oluşum ise 2013 yllından itibaren kademeli olarak bu iki ana akımdan ayrışan mutedil kesimlerin oluşturduğu Ilımlılar (İtidalgeralar) bloğudur. Ilımlılar, yeni dönemin en güçlü siyasi oluşumu olarak siyaseti yönlendirmektedir.

\section{1. İran Tarzı Yerli ve Milliler: Statükocu Muhafazakârlar (Usulgera)}

Usulgera kelimesi genel olarak devrimin prensiplerine bağlılığ 1 sadık kalanları ifade etmek için kullanılır ve reformculuğun karşısında konumlandırılır. ${ }^{55}$ Devrimin ilk yıllarından itibaren Humeyni'nin liderliğine ve devrimin ilkelerine bağlı olan din adamları zamanla gün yüzüne çıan fikir ayrılıkları sebebiyle farklı fraksiyonlar meydana getirmişler ve radikal muhafazakârlığın alternatiflerini üretmişlerdir. Bu grubun yönetimi din adamlarının elindedir. Muhafazakârları destekleyen fanatik kitleler aynı zamanda yeri geldiğinde sokaklarda bu grubun sesi ve koruyucusu olmaktadirlar.

Günümüzde İran siyasal sistemi içerisinde güçlü dini ve siyasal topluluk olan Mücadeleci Din Adamları Topluluğu (Came-ye Ruhaniyat-1 Mubariz), aşırı muhafazakâr tavrından dolayı Usulgeraların en büyük destekçisidir. İran siyasetinde muhafazakâr veya reformist şeklinde ayrışmış birçok ismin birlikte önemli görevlerde bulunduğu bu örgüt, seçimler sırasında destekledikleri adayların listesini açıklayarak, taraftarlarını bu yönde mobilize ederler. ${ }^{56}$ Hamaney'in rehberliğini tartışmasız kabul eden ve mevcut rejimin destekçisi olduğundan dolayı belli imtiyazları da elinde bulunduran Ruhaniyat, İran'ın dini merkezi olan Kum şehrinde de önemli nüfuza sahiptir.

Devrimci ideolojinin bayraktarlığını üstenen, devlet sisteminde teokratik yönetimi ve Velayet-i Fakih anlayışına uygun olarak karizmatik meşruiyet

55 Mehmet Koç, "2016 İran Parlamento Seçimleri,” Iran Araştırmaları Merkezi, 03 Ağustos 2016, Erişim tarihi: 19.03.2019, https://iramcenter.org/2016-iran-parlamentosecimleri/.

56 Pınar Arıkan, "İran İslam Cumhuriyetinde Anayasal Sistem ve Siyasi Partiler," Ortadoğu Stratejik Araştırmalar Merkezi, Rapor no. 112 (Mart 2012): 13, Erişim tarihi: 02.04.2019. http://orsam.org.tr//d_hbanaliz/2012330_112tum.pdf. Yegin, "İran Siyasetini," 31. 
anlayışını savunan muhafazakârlar, ${ }^{57}$ dini konularda geliştirilen eleştirel tavır, toplumsal cinsiyet rolleri ve azınlık hakları konusunda tutucu davranırlar. Ümmetçi çizgisinden taviz vermeyen muhafazakârların yenilikçi kanadı, günümüzde idealist İslamcılığın açmazlarını pragmatist fikirlerle aşmaya çalışmakta, fakat bu konuda özgün bir tavır ortaya koymakta oldukça zorlanmaktadırlar. ${ }^{58}$

Usulgeraların içerisinde rast-1 muhafazakâr (muhafazakâr sağ), rast-1 radikal (radikal sağ), rast-1 modern (modern sağ) ve çep-i modern (modern sol) olmak üzere dört ana grup vardır. ${ }^{59}$ Son cumhurbaşkanllğ 1 seçimlerinde Hamaney'in işaret ettiği ve bu grubun desteklediği yarg1 erki başkanı Reisi'ye halkın verdiği destek \%38'dir.

\subsection{Küresel Sistemle Bütünleşme Eğilimleri: Yenilikçi Reformistler (Islahtalep)}

Liderliğini Hüseyin Hatemi'nin yaptı̆̆1 Islahtalepler, Müslümanların neden zayıf ve düşkün olduğu sorunsalından yola çıkarak İslam Âlemi'nin içerisinde bulunduğu zor durumdan kurtulmanın, genel dogmalarından sıyrılmış gerçek İslam'ın yol göstericiliğinde ve İslam'ın özüne dönerek mümkün olacağını savunmaktadırlar. Islahtalepler, reform talebinde bulunan geniş toplumsal kesimlerin sesi durumundadırlar, ortodoks muhafazakârların aksine dinin farklı yorumlanabileceği savunusunda bulunarak, düşünce ve ifade özgürlüğü ile hukukun üstünlüğünden yana tavır alırlar. ${ }^{60}$ Anayasaya bağl1lıklarından ödün vermemekle birlikte Islahtalepler, anayasanın gelişen koşullar dikkate alınarak ıslah edilerek modernleştirilmesini talep etmekte ve İslam'ın toplum ve siyaset üzerinde baskı aracı olarak kullanılmasına karşı çıkmaktadırlar. ${ }^{61}$ Toplumun reform taleplerine karşılık bulamaması, iktidarla Islahtalepler arasındaki ilişkinin gerilmesine

\footnotetext{
57 Oğuz ve Çakır, Hatemi'nin İran' $\imath, 51$.

58 Sadık Zibakelam, "Muhafazakâr-1 No," Endişe-i Puya 6, sayı 45 (1394): 62.

59 Hamid Reza Celayipur ve Murad Segefi, "Islahtaleb-i Nemorde Est?," Endişe-i Puya 2, say1 8 (1392): 40.

60 Mesud Rezevi, Mütefekkiran-ı Muesser ve Endişe-i Siyasi-e İslam (Tehran: İntişarat-1 Ferzan, 1378), 213.

${ }^{61}$ Keyvan Tabari,“Devrim Sonrası İran'da Hukuk Devleti ve Reform Hareketleri,” çev. İrem Burcu Özkan, İstanbul Üniversitesi Hukuk Fakültesi Mecmuası 72, say1 1 (2014): 920, Erişim tarihi: 05.03.2019, http://dergipark.gov.tr/download/article-file/97904.
} 
sebep olmaktadır. ${ }^{62}$ Reformcu hareketin doğmasında önemli etkenlerden biri de dinin rejim tarafindan politize edilerek siyasal kurumları baskı alt1na alması ve rejime muhalif görüşteki kesimlerin siyasete mobilizasyonunun engellenmesidir. ${ }^{63}$

İslami rejime direkt olarak karşı tavır sergilemeyen reformistlerin en büyük destekçisi Direnişçi Din Adamları Birliği (Mecme-ye Ruhaniyun-u Mubariz)' dir. ${ }^{64}$ Ruhaniyun demokrasi, halk egemenliği, özgürlük, eşitlik ve insan hakları konularına hassasiyet göstermektedir. ${ }^{65}$ Ekonomik politikalar, devletin ekonomideki rolü, özel sektörün konumu ve gelenekçi fıkıh ile dinamik fikıh konularında yaşanan anlaşmazlıklar sebebiyle Ruhaniyat'tan ayrılan örgüt, özellikle gelir paylaşımındaki adaletsizlikler ve yoksullukla mücadele konusunda hassas bir tavır sergilemektedir. ${ }^{66}$

Muhafazakârların siyasal hegemonyasına karşı Reformistler, İslami Cumhuriyet rejiminin "cumhuriyetçi”" niteliğini vurgulamakta ve rejimin meşruiyetinin nihai olarak halkoyuna dayalı olması gerektiğini savunmaktadırlar. ${ }^{67} \mathrm{Bu}$ akımdan beslenerek 1997 seçimlerinde Rafsancani etrafında birleşen modern sağ cenah Hatemi'yi desteklemiştir. Kentli orta sınıflar ve seçkinlerin desteğine sahip reformistler, geniş halk kitlelerinin taleplerine karşılık verebildiği takdirde İran'ın siyasal geleceğini belirlemeye aday görülmektedir. $^{68}$

\subsection{Cepheleşme Yorgunları: Ilımlılar (İtidalgera)}

Devrimin ardından kendilerini sağ ve sol olarak tanımlayan siyasi parti ve gruplar, İran-Irak Savaşı sonrasında meydana gelen gelişmelerin etki-

62 Serge Parsgiyan, "Ne Bitahrim ba Ari be Camia-e Medeni," Endişe-i Puya 2, say1 10 (1392): 43.

63 Arıkan, "İran İslam," 15.

64 Tabari,"Devrim Sonrasi İran'da Hukuk Devleti," 918-919.

65 Ekber Genci, Asıbşinase-yi Guzar ba Dovlet-i Demokratik-e Tosehigera: Tarikhane-i Eşbah, 2. bask1 (Tehran: İntişarat-1 Terh-i No, 1378), 180-181.

${ }_{66}$ Beşiriye, Iran'da Devlet, 109, 137.

67 Serhat Gülmez, "İran'da Reform Hareketinin Geleceği," Birikim Dergisi, say1 149 (Eylül 2001), Erişim tarihi: 28.01.2019, http://www.birikimdergisi.com/birikimyazi/4225/iran-da-reform-hareketinin-gelecegi\#.XIltcqD7QdW.

68 Taşkın, "Devrim Sonrası,” 23. 
siyle yeni (modern) sağ ve yeni (modern) sol tanımlamasını kullanmışlardır. Rafsancani döneminde meydana gelen ekonomik iyileşmemelerin toplumsal tabana yansıması ve Hatemi döneminde yaşanan yeni siyasi süreçle birlikte yeni solcular kendilerini reformist (1slahtalep) olarak tanımlamaya başlamışlar, bunun karşısında gün geçtikçe devrimin temel ilkelerinden uzaklaşıldığ kanaatini taşıyan ve rejime bağl1lı̆̆ şiar edinen yeni sağcılar da kendilerini ilkeci (usulgera) olarak tanımlamıştır. Reformistlerin Hatemi'ye olan desteğini azaltmasıyla cumhurbaşkanı seçilen Ahmedinejad döneminde, devrim anayasasının tavizsiz uygulanması ve dış politikadaki uzlaşmaz tavır sebebiyle giderek otoriterleşen siyasal ortam toplum nezdinde bir endişe durumu meydana getirdi. Bunun yanında muhafazakârlar ile reformistler arasında yaşanan kutuplaşmanın da gün geçtikçe derinleşmesi, radikal siyasetin karşısında reformistlerin siyasal açılım talepleri ve muhafazakârların ekonomik kalkınma önceliklerini eşit derecede önemseyen İtidalgeralar (Ilımlılar) adında yeni bir siyasal hizbin ortaya çıkmasına sebep oldu. ${ }^{69}$ Reformistlerin önemli desteğinin yanında

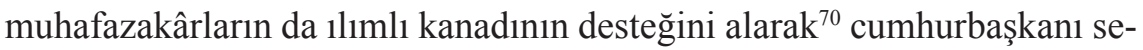
çilen Hasan Ruhani, Ilımlılar bloğunun lideri olarak değerlendirilmektedir.

İlk döneminde iç politikada halkın talep ettiği reformları uygulamaya, dış ilişkilerdeyse rasyonalist tavır sergilemeye çalışan Ruhani, bir yandan da reform taleplerine yeterince karşl1ık veremediği konusunda önemli eleştiriler almaktadır. ${ }^{71}$ Yeni dönemde Ruhani'nin özellikle ekonomik sorunlar sebebiyle yaşanan toplumsal hareketler ve nükleer anlaşmadan çekilen ABD'nin uyguladığı ağır ambargoların da etkisiyle 1 lımlı reformist çizgiden uzaklaştığı ve dış politikasını sertleştirdiği gözlenmektedir. Bütün bu gelişmeler Ruhani’ye olan halk desteğinin gün geçtikçe azalmasına yol açmakta ve 2013'te Umut İttifakı temelinde ortaya çıkan Ilımlılar bloğunun yeniden sorgulamasına sebep olmaktadır.

69 Koç, “2016 İran.”

70 Mustafa Melih Ahıshalı, “İran'da Cumhurbaşkanlı̆̆ Seçimine Doğru," Anadolu Ajansı, 13 Nisan 2017, Erişim tarihi: 08.05.2019, https://www.aa.com.tr/tr/analizhaber/iranda-cumhurbaskanligi-secimine-dogru-/795893.

71 Reza Hoceste Rahimi, "Ruhani ber Nemed Mikubed," Endişe-i Puya 3, sayı 16 (1393): 45. 


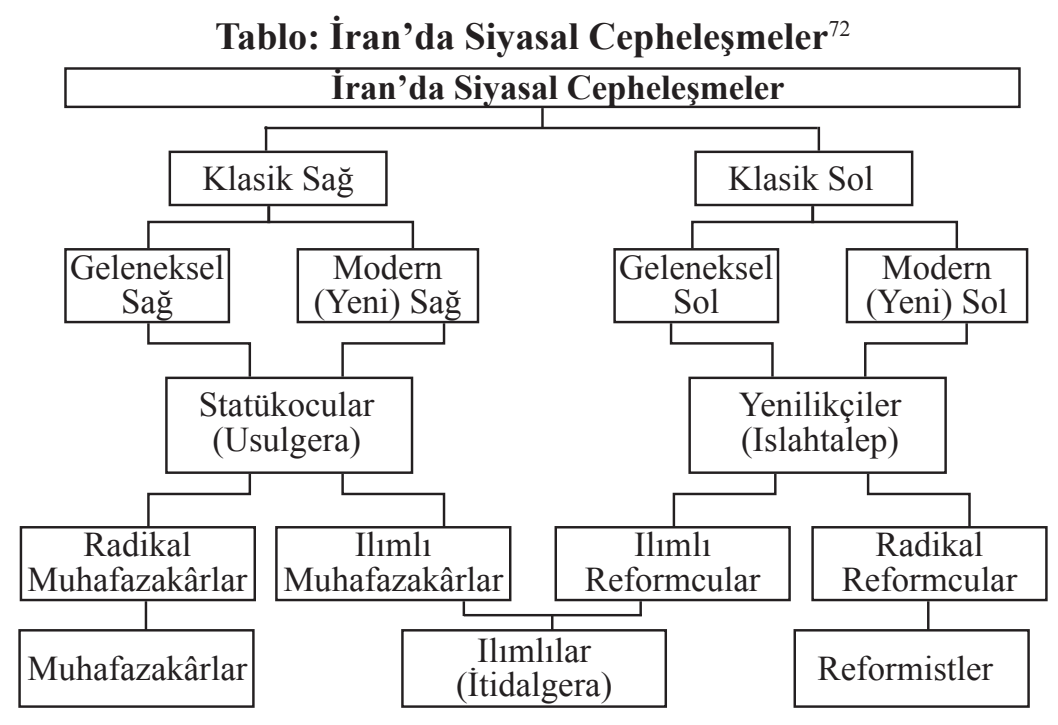

\section{Sonuç}

İran Devrimi, ortak düşman olarak görülen Şah karşıtlığg paydasında birleşen geniş bir toplumsal ittifak sayesinde başarıya ulaştı. Ortak düşmanın ortadan kaldırılmasıyla birlikte asgari müştereklerin bir arada tuttuğu bu ittifak dağıldı ve başlangıçta bütün toplumsal kesimlerin sahiplendiği devrim kitlesel özelliğini kaybetti. Devrim sonrasında iktidarı eline alan İslamcılar önce farklı ideolojileri devlet yönetiminden uzaklaştırdı, ardından da özellikle siyasal ve toplumsal alanda ulemanın sınırsız denetimine sıcak bakmayan, dinin siyasetle olan yakın ilişkisini sorgulayan farklı hizipleri kendi içerisinden temizledi. Milliyetçi ve sosyalist yapıların sistemden tasfiye edilmesiyle birlikte, Humeyni'nin güçlü karizması önderliğinde din adamları sistemi ele geçirdi. Devrimci elitlerin dizayn ettiği politik ortama mobilize olamayarak siyaset sahnesinden uzaklaştırılan farklı görüşler, bu kez statükocu rejimin alternatifi olarak reform yanlısı yeni bir ittifakı meydana getirdi. Humeyni henüz hayattayken İran siyasal sistemi içerisinde olgunlaşmaya başlayan cepheleşmeler günümüzde tamamıyla belirginleşmiş durumdadır. Bugün İran'da üç ana cephe aktif siyaseti yönlendirme gücüne sahip ve siyaseti domine eden güçlü aktörler bu cepheleşmelerin belirleyicileri konumunda yer alıyor. Bunun yanında devrimci ideolojinin

72 Tablo araştırmacılar tarafından oluşturulmuştur. 
birikimi ve karizmatik liderlik anlayışı siyasal yaşamın belirleyicisi durumunda. Muhafazakârlar Velayet-i Fakih kurumunun sistemi şekillendirmesini, din adamlarının devletteki etkin konumunu ve içe kapalı bir ekonomi modelini benimsemekte, Reformistler ulemanın dini konular dışında sistem içerisindeki nüfuzunu eleştirmekte ve küresel sistemle bütünleşmeyi savunmaktadır. Ilımlılar ise iki ana grubun gelgitlerinden yorulan ve radikalize olmuş siyasi ortamdan bunalan toplumsal kesimlerin sözcüsü olma niyetindedir. Bunlara karşılık günümüze gelen bu cepheleşmelerle birlikte, siyasete katılım olanağına sahip aktif siyasal aktörlerin tamamının Humeyni'nin Cübbesi'nden çıktığını ve onun anlayışının farklı yorumlaryyla güncelleştirilmiş formları olduğunu unutmamak gerekir.

\section{Kaynakça}

Arıkan, Pınar. "İran İslam Cumhuriyetinde Anayasal Sistem ve Siyasi Partiler." Ortadoğu Stratejik Araş̧tırmalar Merkezi, Rapor no. 112 (Mart 2012). Erişim tarihi: 02.04.2019. http://orsam.org.tr//d_ hbanaliz/2012330_112tum.pdf.

Beneton, Philippe. Muhafazakârlık. Çeviren Cüneyt Akalın. İstanbul: İletişim Yayınları, 2011.

Bestinigâr, Muhammed. "Talegani An Çenan Kebûd." Endişe-i Puya 2, say1 14 (1393): 29-32.

Beşiriye, Hüseyin. Iran'da Devlet, Toplum ve Siyaset. Çeviren Mehmet Koç. İstanbul: Ağaç Kitabevi Yayınları, 2009.

Beşiriye, Hüseyin. Zeminaha-yı İçtimai-ye İnkılab-e Iran. 2. baskı. İngilizceden çeviren Ali Erdestani. Tehran: Neşr-i Nigâh-1 Moesser, 1394.

Bobbio, Norberto. Săg ve Sol: Bir Politik Ayrımın Anlamı, Çeviren Zühal Y1lmaz. Ankara: Dost Kitabevi, 1999.

Buchta, Wilfried. Who Rules Iran?: The Structure of Power in the Islamic Republic. Washington: The Washington Institute for Near East Policy and the Konrad Adenauer Stiftung, 2000. Erişim tarihi: 09.05.2018. https:// www.washingtoninstitute.org/uploads/Documents/pubs/WhoRulesIran.pdf.

Buzan, Barry. İnsanlar, Devletler \& Korku. Çeviren Emre Çıtak. İstanbul: Röle Akademik Yayıncılık, 2015. 
Celayipur, Hamid Reza ve Segefi, Murad. "Islahtaleb-i Nemorde Est?." Endişe-i Puya 2, say1 8 (1392): 39-45.

Creswell, John W. Educational Research: Planning, Conducting, and Evaluating Quantitative and Qualitative Research. 4th edition. Boston: Pearson Education Inc., 2012. Erişim tarihi: 11.03.2019. http://basu.nahad. ir/uploads/creswell.pdf.

Duman, Fatih. "Modern Siyasal İdeolojiler." içinde Feodaliteden Küreselleşmeye: Temel Kavram ve Süreçler, editör Tevfik Erdem, 111-160. Ankara: Lotus Yayınevi, 2006.

Genci, Ekber. Asıbşinase-yi Guzar ba Dovlet-i Demokratik-e Tosehigera: Tarikhane-i Eşbah. 2. baskı. Tehran: İntişarat-1 Terh-i No, 1378.

Göksu, Muzaffer Emin. “Sağc1lık ve Solculuğun Ötesinde.” Tezkire Dergisi 9, say1 17 (Ekim/Kasım 2000): 57-64. Erişim tarihi: 15.02.2019. http:// isamveri.org/pdfdrg/D01353/2000_17/2000_17_GOKSUME.pdf.

Gülmez, Serhat. "Iran'da Reform Hareketinin Geleceği." Birikim Dergisi, say1 149 (Eylül 2001), Erişim tarihi: 28.01.2019. http://www. birikimdergisi.com/birikim-yazi/4225/iran-da-reform-hareketiningelecegi\#.XIltcqD7QdW.

Hakyemez, Cemil. "Günümüz İran Şiiliğinde Mehdilik Beklentisinin Siyasi Boyutu." Uluslararası Mehdilik Sempozyumu Bildirileri. editörler Mehmet Tıraşçı, Hasan Özalp, Maruf Çakır, 515-524. Sivas: Cumhuriyet Üniversitesi Matbaas1, 2018, Erişim tarihi: 12.04.2019, http://www. cumhuriyet.edu.tr/userfiles/file/Mehdilik_Sempozyumu.pdf.

Heywood, Andrew. Siyasî İdeolojiler: Bir Giriş. 5. baskı. Çevirenler Ahmet Kemal Bayram, Özgür Tüfekçi, Hüsamettin İnanç, Şeyma Akın, Buğra Kalkan. Ankara: Adres Yayınları, 2013.

İntizam, Emir Abbas. An Su-ye Ittiham: 1357 Şehriver-1360 Hordad. Cilt 1, 2. bask1. Tehran: Neşr-i Ney, 1381.

Kartal, Kemal. Yöntembilim. Ankara: Detay Yayıncılık, 2015.

Kayacan, Murat. "Sağ(c1lık) ve Sol(culuk) Kavramları ile Bu Kavramların Kur'an Meallerindeki Kullanımları." Marife Dergisi 10, sayı 3 (Kış 2010): 291-306. Erişim tarihi: 11.01.2019. http://dergipark.gov.tr/download/ article-file/494078. 
Kesgin, Ahmet. "İnsanın Meşruiyet Kaygısı ya da Kendini Sağcı Olarak İnşa Etmek.” Toplum Bilimleri Dergisi 5, say1 9 (Ocak-Haziran 2011): 191-200. Erişim tarihi: 18.02.2019. http://www.toplumbilimleri.com/files/ f131f25e-03d2-4fd4-8d0c-324a3ad8803812\%20Ahmet\%20KESGIN.pdf.

Moazami, Behrooz. Iran'da Devlet, Din ve Devrim, 1796'dan Bugüne. Çeviren Bahar Bilgen. İstanbul: İletişim Yayınları, 2018.

Nisbet, Robert A. Muhafazakârlı: Düss ve Gerçek. Çevirenler M. Fatih Serenli, Fatih Bülbül. Ankara: Kadim Yayınları, 2007.

Oğuz, Sami. Çeviren. "Görkemli 23 Mayıs Destanının Değerlendirilmesi." Birikim Dergisi, say1 101 (Eylül 1997), Erişim tarihi: 10.02.2019. http://www.birikimdergisi.com/birikim-yazi/4674/gorkemli-23-mayisdestaninin-degerlendirilmesi\#.XIltEaD7QdV.

Oğuz, Sami ve Ruşen Çakır. Hatemi'nin İran ’ı. İstanbul: İletişim Yayınları, 2000. Özbudun, Ergun. Siyasal Partiler. 3. baskı. Ankara: Sevinç Matbaası, 1979. Özkazanç, Alev. "Yeni Sağdan Sonra: Yeni Sol, Siyasi İktidar ve Meşruiyet." Ankara Üniversitesi Siyasal Bilgiler Fakültesi GETA Tartışma Metinleri, say1 24 (Mart 2000). Erişim tarihi: 18.02.2019. http://politics. ankara.edu.tr/dergi/tartisma/2000/siyasi-iktidar.pdf.

Özipek, Bekir Berat. Muhafazakârlı: Akıl Toplum ve Siyaset. Ankara: Liberte Yayınları, 2004.

Özsel, Doğancan. "Radikalizm ve Muhafazakâr Düşünce: Yeni Muhafazakârlık Ne Kadar Yeni?.” içinde Yeni Să̆ Yeni Sol, derleyen Armağan Öztürk, 417442. Ankara: Phoenix Yayınevi, 2010.

Parsgiyan, Serge. "Ne Bitahrim ba Ari be Camia-e Medeni." Endişe-i Puya 2, say1 10 (1392): 43-47.

Rahimi, Reza Hoceste. "Ruhani ber Nemed Mikubed." Endişe-i Puya 3, say1 16 (1393): 43-46.

Rezevi, Mesud. Mütefekkiran-ı Muesser ve Endişe-i Siyasi-e İslam. Tehran: İntişarat-1 Ferzan, 1378.

Şeyhanlıŏlu, Hüseyin. "Siyasal Muhafazakârlığın Temel İlkeleri." Dicle Üniversitesi İktisadi ve İdari Bilimler Fakültesi Dergisi 1, sayı 1 (Kış 2011): 84-107. Erişim tarihi: 21.02.2019. http://dergipark.gov.tr/download/ article-file/370660. 
Tabari, Keyvan. "Devrim Sonrası İran'da Hukuk Devleti ve Reform Hareketleri." Çeviren İrem Burcu Özkan. İstanbul Üniversitesi Hukuk Fakültesi Mecmuası 72, sayı 1 (2014): 917-933. Erişim tarihi: 05.03.2019. http://dergipark.gov.tr/download/article-file/97904.

Taşkın, Yüksel. “Devrim Sonrası İran'da Siyaset: Aktörler, Stratejiler ve Gelecek." İstanbul Üniversitesi Siyasal Bilgiler Fakültesi Dergisi, say1 39 (Ekim 2008): 21-53. Erişim tarihi: 06.04.2019. http://dergipark.gov.tr/ download/article-file/5309.

Tuzcu, Pınar. "Yeni Sağ, Muhafaza(kâr)lık ve Göç." Yeni Să̆ Yeni Sol, derleyen Armağan Öztürk, 473-490. Ankara: Phoenix Yayınevi, 2010.

Uçar, Metin. "Klasik Bir Ayrımın Ötesine Geçememek: Siyasal Farklılığın Ölçütü Olarak Sağ-Sol.” Liberal Düşünce, sayı 40, (Güz 2005): 331249. Erişim tarihi: 28.02.2019. http://www.libertedownload.com/LD/ arsiv/40/18-metin-ucar-siyasal-farkliligin-olcutu-olarak-sag-sol.pdf.

Uluçakar, Mustafa. "Muhafazakâr Demokrasi Söylemi Üzerine Bir İnceleme." Alternatif Politika 10, say1 3 (2018): 349-373. Erişim tarihi: 03.03.2019. http://alternatifpolitika.com/site/cilt/10/sayi/3/3-UlucakarMuhafazakar-Demokrasi-Soylemi.pdf.

Üşenmez, Özgür. "İran ve Rejim İstikrarı.” Dokuz Eylül Üniversitesi Sosyal Bilimler Enstitüsü Dergisi 17, say1 3 (2015): 389-407. Erişim tarihi: 28.02.2019. https://dx.doi.org/10.16953/deusbed.90907.

Üşür, Serpil. Din, Siyaset ve Kadın: Iran Devrimi. İstanbul: Alan Yayınc1lık, 1991.

Vural, Mehmet. Siyaset Felsefesi Açısından Muhafazakârlık. 2. bask1. Ankara: Elis Yayınları, 2007.

Yegin, Abdullah. "İran Siyasetini Anlama Kilavuzu." Siyaset, Ekonomi ve Toplum Araştırmaları Merkezi, Yayın no. 25 (Haziran 2013). Erişim tarihi: 23.03.2019. http://file.setav.org/Files/Pdf/20130610163244_iran-siyaseti_ web.pdf.

Yıldırım, Ali. "Nitel Araştırma Yöntemlerinin Temel Özellikleri ve Eğitim Araştırmalarındaki Yeri ve Önemi." Eğitim ve Bilim 23, sayı 112 (1999): 7-17. Erişim tarihi: 14.01.2019. http://egitimvebilim.ted.org.tr/index.php/ EB/article/view/5326/1485. 
Zibakelam, Sadık. "Muhafazakâr-1 No.” Endişe-i Puya 6, sayı 45 (1394): 62-63.

\section{Internet Kaynakları}

Ahıshalı, Mustafa Melih. "İran'da Cumhurbaşkanlığı Seçimine Doğru." Anadolu Ajansl, 13 Nisan 2017, Erişim tarihi: 08.05.2019. https:// www.aa.com.tr/tr/analiz-haber/iranda-cumhurbaskanligi-seciminedogru-/795893.

Ametbek, Dinmuhammed. "İran Cumhurbaşkanlığ 1 Seçimleri." Ankara Kriz ve Siyaset Araştırmaları Merkezi, 15 Mayıs 2017, Erişim tarihi: 12.01.2019. https://ankasam.org/iran-cumhurbaskanligi-secimleri/.

Caner, Mustafa. "Ruhani'nin Politik Performansı." Sakarya Üniversitesi Ortadoğu Enstitüsü, 01 Eylül 2014, Erişim tarihi: 07.05.2019. https:// ormer.sakarya.edu.tr/20,3,12,ruhani_nin_politik_performansi. html?hilight=ruhani|reformist.

Keskin, Mustafa. "İran'da Siyasal Ayrışmanın Temelleri: Sağ ve Sol." Akademik Perspektif, 31 Mayıs 2013, Erişim tarihi: 21.04.2018. http:// akademikperspektif.com/2013/05/31/iranda-siyasal-ayrismanintemellerisag-ve-sol/.

Koç, Mehmet. "2016 İran Parlamento Seçimleri." Iran Araştırmaları Merkezi, 03 Ağustos 2016, Erişim tarihi: 19.03.2019. https://iramcenter. org/2016-iran-parlamento-secimleri/.

Şahit, Babek. "İran'ın Millî Güvenliği ve Dinî Tarikatların Tehdidi.” Tebriz Araştırmaları Enstitüsü, 20 Şubat 2018, Erişim tarihi: 09.04.2019, http:// tebaren.org/?p=1371. 